Case Report

\title{
Labyrinthine fistula size as a prognostic factor for postoperative hearing deterioration
}

\author{
Ratna Dwi Restuti*, Harim Priyono*, Ayu Astria Sriyana*, \\ Rangga Rayendra Saleh*, Eka Dian Safitri** \\ *Department of Otorhinolaryngology - Head and Neck Surgery \\ **Clinical Epidemiology and Evidence Based Medicine Unit, \\ Faculty of Medicine, Universitas Indonesia, Dr. Cipto Mangunkusumo Hospital, Jakarta
}

\begin{abstract}
Background: A labyrinthine fistula is an abnormal opening in the bony capsule of the inner ear, such as cochlea or semi-circular canals that may occur as a complication of chronic suppurative otitis media (CSOM) with cholesteatoma. Purpose: To find out the relation of the size of labyrinthine fistula as a prognostic factor of hearing deterioration after a complete cholesteatoma removal. Case report: Two cases of labyrinthine fistula in CSOM with cholesteatoma, along with preoperative and postoperative audiometry results. Clinical question: Does the labyrinthine fistula size in CSOM with cholesteatoma patients could serve as a prognostic factor in the postoperative hearing outcome? Review method: A structured, evidence-based literature search using Pubmed, Proquest and Cochrane to find studies of labyrinthine fistula as a complication of CSOM. The articles were selected based on eligibility criteria i.e. surgery procedure, labyrinthine fistula measurement, and postoperative evaluation of hearing function. The appraisal of each article used Oxford critical appraisal independently for prognostic study and systematic review. Result: Two studies met the inclusion criteria. One article used cohort retrospective method valid based on appraisal for prognostic studies. The other article used a systematic review method which had low validity. Conclusion: Fistula size is still debatable as a postoperative prognostic factor for hearing deterioration in CSOM with cholesteatoma. Larger sample size and better methods of study are necessary to resolve the clinical question.
\end{abstract}

Keywords: chronic suppurative otitis media (CSOM), cholesteatoma, labyrinthine fistula, fistula size

\section{ABSTRAK}

Latar belakang: Fistula labirin adalah terbukanya dinding tulang pada koklea atau kanalis semisirkularis yang merupakan suatu komplikasi dari otitis media supuratifkronik (OMSK) tipe bahaya. Tujuan: Untuk menjawab pertanyaan klinis terkait hubungan antara ukuran fistula labirin dengan prognosis penurunan pendengaran pasca operasi pengangkatan kolesteatoma. Laporan kasus: Dua kasus fistula labirin pada penderita OMSK tipe bahaya, disertai dengan hasil pemeriksaan audiometri pendengaran sebelum dan sesudah operasi. Pertanyaan klinis: Apakah ukuran fistula labirin pada kasus OMSK dengan kolesteatoma dapat menjadi faktor penentu prognosis untuk hasil pemeriksaan pendengaran pasca operasi? Telaah literatur: Pencarian literatur berbasis bukti menggunakan Pubmed, Proquest dan Cochrane terkait fistula labirin pada kasus OMSK. Kriteria inklusi studi berdasarkan teknik operasi, ukuran fistula dan evaluasi pendengaran pasca operasi. Metode Oxford critical appraisal digunakan untuk studi prognosis pada satu artikel, dan digunakan systematic review untuk artikel lainnya. Hasil: Dari pencarian literatur terdapat dua artikel yaitu studi kohort retrospektif, dan systematic review yang memenuhi kriteria inklusi. Hasil telaah literatur menunjukan bahwa study kohort retrospektif memiliki validitas cukup baik, sedangkan studi systematic review memiliki validitas yang kurang baik. Kedua artikel ini memiliki hasil yang berbeda dalam hubungan ukuran fistula labirin dengan prognosis penurunan pendengaran pasca operasi. Kesimpulan: Ukuran fistula sebagai faktor prognosis penurunan pendengaran pasca operasi pada kasus OMSK tipe bahaya masih 
memerlukan penelitian dengan sampel yang lebih banyak, dan metode yang lebih baik untuk dapat menjawab pertanyaan klinis.

Kata kunci: otitis media supuratif kronik (OMSK), kolesteatoma, fistula labirin, ukuran fistula

Correspondence address: Ratna Dwi Restuti, Department of Otorhinolaryngology Head and Neck Surgery, Faculty of Medicine, Universitas Indonesia-Cipto Mangunkusumo Hospital. J1. Diponegoro No.71, Jakarta 10430, Indonesia. Email: ratna.drest@gmail.com

\section{INTRODUCTION}

Chronic suppurative otitis media (CSOM) with cholesteatoma contributes to bone erosion of the cochlea or semi-circular canal due to the action of collagenase or its pressure. A labyrinthine fistula is an abnormal opening in the bony capsule of the inner ear, such as cochlea or semi-circular canals. ${ }^{1}$ The semi-circular canal (SCC) is connected to the cochlea; thus, labyrinthine fistula could lead to sensorineural hearing loss (SNHL). Preoperative deafness ranges approximately from $12 \%$ to $30 \% .^{2}$ Preoperative hearing changes depend on the inner ear infection extensiveness. Should purulent labyrinthitis occurred, hearing recovery could not be expected.

The most common inner ear fistula due to cholesteatoma involvement is in lateral SCC, followed by promontorium, superior SCC, and posterior SCC. ${ }^{3}$ If the fistula is left untreated,complication in the inner ear such as vertigo, SNHL, purulent labyrinthitis, and meningitis could occur.

According to Sanna et al. ${ }^{4}$ fistula size in labyrinthine fistula can be classified as small ( 0.5 to $1 \mathrm{~mm})$, medium ( 1 to $2 \mathrm{~mm}$ ), and large $(>2 \mathrm{~mm})$. Ikeda et al..$^{5}$ differentiated the size of labyrinthine fistula as small size $(\leq 3 \mathrm{~mm})$ and large fistula $(>3 \mathrm{~mm})$. The fistula size could be measured preoperatively using a CT scan image by evaluating the defect in millimeters, measuring from the outer surface of the inner ear cavity adjacent to areas of the bone defect. ${ }^{6}$ Several studies evaluated fistula size and the correlation with the postoperative hearing test showed various results.

These two cases were reported to find out whether the fistula size served as a prognostic factor for postoperative hearing prediction.

\section{CASE REPORT}

\section{Case 1}

A 55 years-old female patient came to ENT-HL clinic with a 5 months history of left ear discharge. The discharge was thick, yellowish, and frequently smeared with blood. Right ear examination was within normal limits. The left ear had a notable seromucous secretions, cholesteatoma and granulation tissue. The fistula test showed no noticeable nystagmus. Head thrust test suggested a left vestibular weakness. Audiometry revealed a mild conduction hearing loss in the left ear $(38.75 \mathrm{~dB})$ and a normal hearing threshold in the right ear. High Resolution CT (HRCT) mastoid examination revealed sclerotic appearance, destruction in the mastoid antrum, additus ad antrum, tympanic cavity, and epitympanum. There was a lateral wall destruction of the tympanum facial canal and mastoid segments. A fistula size of 2.3 $\mathrm{mm}$ (length) and $1 \mathrm{~mm}$ (depth) was found on the lateral semicircular canal (Figure 2). This patient was diagnosed as CSOM with cholesteatoma and labyrinthine fistula.

The patient underwent canal wall down mastoidectomy surgery. Cholesteatoma was found in the antrum and epitympanum area, and completely removed. The ossicles were 
eroded, and only the stapes was left intact. Cholesteatoma was covering the lateral SCC, and after gently removing the matrix over labyrinthine fistula, the labyrinth membrane was found still intact. A cartilage graft with superficial fascia of the temporalis muscle was used to close the fistula. Patient was given intravenous dexamethasone $5 \mathrm{mg}$ during surgery.
Audiometry examination one month post-surgery revealed moderate conductive deafness in the left ear $(45 \mathrm{~dB})$. Bone conduction thresholds of preoperative and postoperative were summarized in Table 1. There was a $7.5 \mathrm{~dB}$ difference of preoperative and postoperative bone threshold.

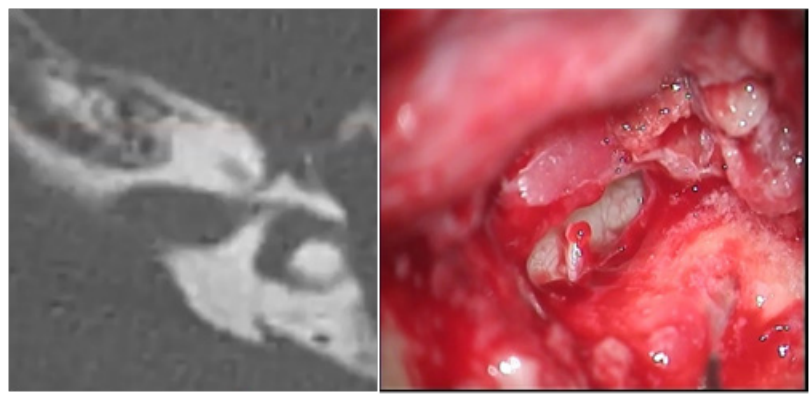

Figure 1. HRCT mastoid of the left ear and intraoperative finding

\section{Case 2}

A 26 years-old female patient came to the ENT-HN outpatient clinic complaining of left ear discharge with pain for 6 months. The left ear examination revealed a retracted pocket on the tympanic membrane. The fistula test did not reveal nystagmus, nor vertigo sensation. The preoperative audiometry result was severe conduction HL in the left ear (67.5 $\mathrm{dB}$ ) and a normal hearing threshold in the right ear. The head thrust examination results suggested left vestibular weakness. The result of the Dizziness Handicap Index (DHI) scoring was 56. HRCT mastoid examination revealed left mastoiditis with cholesteatoma involving the mastoid antrum and middle ear, destruction of the posterior wall of the external acoustic canal. There was a fistula sized $2.1 \mathrm{~mm}$ (length) and $1 \mathrm{~mm}$ (depth) in the lateral SCC (Figure 2).

The patient underwent canal wall down mastoidectomy. Cholesteatoma was found in the antrum and epitympanum area. The cholesteatoma was removed thoroughly over the eroded semicircular canal. Lateral and posterior SCC appeared eroded, revealing the membranous labyrinth. A cartilage graft with superficial fascia of the temporalis muscle was used to close the fistula. Intravenous dexamethasone $5 \mathrm{mg}$ was administered during surgery. One month post-surgery audiometry examination revealed a severe conductive deafness $(70 \mathrm{~dB})$. There was no difference in preoperative and postoperative bone thresholds (Table 1).

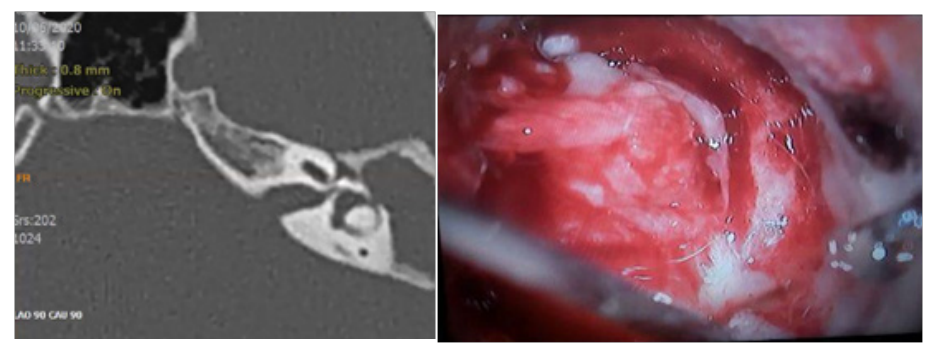

Figure 2. HRCT mastoid of the left ear and intraoperative finding 
Table 1. Bone conduction preoperative and postoperative (affected ear)

\begin{tabular}{|c|c|c|c|c|c|c|c|c|c|c|c|c|}
\hline \multirow[t]{2}{*}{ Patient } & \multirow[t]{2}{*}{$\begin{array}{l}\text { Fistula } \\
\text { Size } \\
\end{array}$} & \multicolumn{4}{|c|}{$\begin{array}{c}\text { Bone Conduction Pre op- } \\
\text { erative (affected ear) }\end{array}$} & \multicolumn{6}{|c|}{$\begin{array}{l}\text { Bone Conduction Post } \\
\text { operative (affected ear) }\end{array}$} & \multirow{2}{*}{$\begin{array}{l}\text { Pre-Post } \\
\text { op Differ- } \\
\text { ence }\end{array}$} \\
\hline & & $\begin{array}{l}500 \\
\mathrm{~Hz}\end{array}$ & $\begin{array}{c}1000 \\
\mathrm{~Hz}\end{array}$ & $\begin{array}{c}2000 \\
\mathrm{~Hz}\end{array}$ & $\begin{array}{c}4000 \\
\mathrm{~Hz}\end{array}$ & Average & $\begin{array}{l}500 \\
\mathrm{~Hz}\end{array}$ & $\begin{array}{c}1000 \\
\mathrm{~Hz}\end{array}$ & $\begin{array}{c}2000 \\
\mathrm{~Hz}\end{array}$ & $\begin{array}{c}4000 \\
\mathrm{~Hz}\end{array}$ & Average & \\
\hline 1 & & 10 & 10 & 20 & 10 & $12.5 \mathrm{~dB}$ & 15 & 15 & 25 & 25 & $20 \mathrm{~dB}$ & $\begin{array}{c}7.5 \mathrm{~dB} \\
\text { (Worsened } \\
<10 \mathrm{~dB} \text { ) }\end{array}$ \\
\hline 2 & & 20 & 15 & 20 & 20 & $18.5 \mathrm{~dB}$ & 20 & 15 & 20 & 20 & $18.5 \mathrm{~dB}$ & No change \\
\hline
\end{tabular}

\section{CLINICAL QUESTION}

Does the labyrinthine fistula size in CSOM with cholesteatoma patients could serve as a prognostic factor in the postoperative hearing outcome?

\section{PICO}

P: Patient with labyrinthine fistula as a complication of CSOM with cholesteatoma that underwent surgery.

I: Fistula size (measured by CT scan or during surgery).

C: -

$\mathrm{O}$ : Hearing function of minimum 1 month postoperative (audiometry bone conduction).

\section{METHODS}

Literature search using Pubmed, Proquest and Cochrane with keywords: labyrinthine fistula, cholesteatoma removal, hearing, and audiometry. The search was limited to 10 years filter concerning the tools and equipment used in the surgery that could influenced the procedure and hearing outcome. Oxford critical appraisal tools were used for each included study.

Inclusion criteria were cohort study and randomized controlled trial, with keywords: "operation procedure", AND "fistula size", AND "pre and postoperative bone conduction threshold". The exclusion criteria were not a CSOM complication case, and non-English text and no full-text availability.

\section{RESULT}

The search was conducted on February $25^{\text {th }} 2021$ and found 195 articles. After removing duplicates and excluded studies based on exclusion criteria, 23 articles were regarded appropriate. After reviewing the full text, 21 articles were considered as unsuitable, remaining 2 articles to be analyzed.

\section{DISCUSSION}

The fistula size had been studied as a prognostic factor for the postoperative hearing with contradicting results. Both of our cases had labyrinthine fistula sized of more than $2 \mathrm{~mm}$ and had a good postoperative hearing outcome. All studies mentioned that a change of $10 \mathrm{~dB}$ or more in the bone conduction threshold was considered clinically significant. ${ }^{1,5,7-9}$ One of our cases had an average bone threshold conduction change of less than $10 \mathrm{~dB}$ at one month postoperative, which was considered as not clinically significant hearing deterioration based on the following literature.

Ikeda et al. ${ }^{5}$ stated that poorer post operative bone conduction hearing was correlated with larger fistulae. Preservation of bone conduction hearing threshold in ears with residual hearing was attained in $97 \%$ of the smaller-fistula group and $71 \%$ of the larger fistula group. Rah et al. ${ }^{9}$ also found a significant difference between fistula size and postoperative bone conduction threshold.

On the contrary, several studies stated that fistula size does not correlate with the 
postoperative bone conduction threshold. A systematic review by Lim et al. ${ }^{7}$ that included labyrinthine fistula size as a prognostic factor used cut off point as large as $2 \mathrm{~mm}$, found no significant difference between smaller size fistula and larger size fistula. Moon et al. ${ }^{1}$ and Jang et al. ${ }^{8}$ also found no correlation between fistula size and postoperative hearing threshold. All studies had low quality of evidence and high bias, therefore more studies with a larger sample and better methods were necessary to precisely answer our clinical question.

SNHL may occur due to the loss of inner ear function as a result of iatrogenic injuries when the matrix over the labyrinthine fistula is completely removed. ${ }^{2}$ All of these studies patients were underwent complete cholesteatoma removal regardless of the technique. Factors often associated with postoperative hearing deterioration include the labyrinthine fistula size and the applied surgical technique. Another factor that may relate to the postoperative hearing outcome was intraoperative corticosteroid injection, as reported in the study by Jang et al. ${ }^{8}$ Both of our cases were given dexamethasone steroid injection intra-operatively. The injection may contribute to a good hearing outcome, unfortunately, the studies that reported the effectiveness of intraoperative corticosteroid on bone conduction hearing had only a small number of cases. ${ }^{10,11}$

A larger sample size and better methods should be considered in future studies pertaining to other factors which contribute to the outcome of postoperative hearing.

Fistula size was still debatable as a postoperative prognostic factor for hearing deterioration. Other factors such as surgical technique and intraoperative steroid administration may contribute to the prognosis. Larger sample size and better methods of study are necessary to answer the clinical question.

\section{REFERENCE}

1. Moon IS, Kwon MO, Park CY, et al. Surgical management of labyrinthine fistula in chronic otitis media with cholesteatoma. Auris Nasus Larynx. 2012; 39(3): 261-4.

2. Geerse S, de Wolf MJF, Ebbens FA, van Spronsen E. Management of labyrinthine fistula: hearing preservation versus prevention of residual disease. Eur Arch Oto-Rhino-Laryngology. 2017; 274(10): 3605-12.

3. Copeland BJ, Buchman CA. Management of labyrinthine fistulae in chronic ear surgery. Am J Otolaryngol. 2003; 24(1): 51-60.

4. Sanna M, Zini C, Gamoletti R, Taibah AK, Russo A, Scandellari R. Closed versus open technique in the management of labyrinthine fistulae. Am J Otol. 1988; 9(6): 470-5.

5. Ikeda R, Kobayashi T, Kawase T, Oshima T, Sato T. Risk factors for deterioration of bone conduction hearing in cases of labyrinthine fistula caused by middle ear cholesteatoma. Ann Otol Rhinol Laryngol. 2012; 121(3): 162-7.

6. Sone M, Yoshida T, Naganawa $\mathrm{S}$, et al. Comparison of computed tomography and magnetic resonance imaging for evaluation of cholesteatoma with labyrinthine fistulae. Laryngoscope. 2012; 122(5): 1121-25.

7. Lim J, Gangal A, Gluth MB. Surgery for Cholesteatomatous Labyrinthine Fistula: A Systematic Review. Ann Otol Rhinol Laryngol. 2017; 126(3): 205-15.

8. Jang CH, Jo SY, Cho YB. Matrix removal of labyrinthine fistulae by non-suction technique with intraoperative dexamethasone injection. Acta Otolaryngol. 2013; 133(9): 910-15.

9. Rah YC, Han WG, Joo JW, et al. Onestage complete resection of cholesteatoma with labyrinthine fistula: hearing changes and clinical outcomes. Ann Otol Rhinol Laryngol. 2018; 127(4): 241-8.

10. Stephenson M-F, Saliba I. Prognostic indicators of hearing after complete resection of cholesteatoma causing a labyrinthine fistula. Eur Arch oto-rhino-laryngology. 2011; 268(12): 1705-11.

11. Dornhoffer JL, Milewski C. Management of the open labyrinth. Otolaryngol Neck Surg. 1995; 112(3): 410-14. 